ISSN : 2598-0521

\title{
ANALISIS USAHA PENANGKARAN BURUNG MURAI BATU (Cophycus malabaricus) DI KABUPATEN OKU TIMUR
}

\author{
Hariyono \\ Sekolah Tinggi Ilmu Pertanian Belitang \\ Jln.Kampus Pertanian No.3 Belitang Kab.OKU Timur Prov.Sumatera Selatan \\ e-mail: hariyono.ss@gmail.com
}

\begin{abstract}
The purpose of this study is to 1. Know the cost and income of the Murai Batu bird breeding business. 2. Knowing the feasibility level of the Murai Batu bird breeding business. This research was conducted in Sidogede Village, Belitang District and in Bangun Harjo Village, Buay Madang Timur District, East OKU Regency. This research was conducted in 2017. The research method used is the census method of two samples from two populations of stone magpie breeding business in Sidogede Village, Belitang District, East OKU Regency and in Bangun Harjo Village, Buay Madang Timur District, East OKU Regency. The data obtained from the field will be processed tabulated and mathematically, which includes production costs, revenue, income, calculating the $R / C$ ratio, and analyzing financial feasibility. Based on the results of the research that has been done, the following conclusions can be drawn: 1. The amount of income from the magpie bird breeding is Rp. 13,000,000, with a total cost of Rp. 1,301,254.86 so that an income of Rp. 11,689,745.14. 2. NPV (Net Present Value) analysis in the breeding of stone magpies is IDR 813,474,900. With the IRR (Internal rate of Return) value is $71.8 \%$, which means that it is greater than the bank interest rate of 18\%, so that the magpie stone breeding business is feasible to be developed. The Net B / C value is 3.26, which is greater than zero, so the business is feasible to develop.
\end{abstract}

Key words : Cophycus malabaricus, Net present value, Internal rate of return

\section{PENDAHULUAN}

\section{A. Latar Belakang}

Indonesia merupakan salah satu negara agraris yang memiliki sumber daya alam berlimpah, tidak hanya berpotensi besar dalam perkembangan pertanian pangan dan perkebunan saja tetapi dalam sektor peternakan. Peternakan di Indonesia erat kaitannya dengan pembangunan nasional bahkan pemerintah menjadikan peternakan sebagai komponen revitalisasi pertanian. Peternakan secara strategis berperan dalam penanggulangan kemiskinan. Hal ini sesuai dengan tiga sasaran utama program penanggulangan kemiskinan yang telah ditetapkan oleh Pemerintah yakni: menurunnya persentase penduduk yang berada di bawah garis kemiskinan menjadi 8,2 persen, terpenuhinya kecukupan pangan yang bermutu dan terjangkau, dan terpenuhinya pelayanan kesehatan yang bermutu (Vernahy, 2013).

Seiring dengan meningkatnya pengetahuan masyarakat mengenai kesehatan yang bermutu dan pemenuhan kebutuhan gizi, maka meningkat pula kebutuhan akan produk yang berasal dari peternakan seperti daging, susu, dan telur. Hal ini sesuai dengan peran peternakan sebagai penyedia protein, energi, vitamin, dan mineral. Selain berperan dalam memenuhi kebutuhan dasar manusia akan sumber nutrisi yang baik, peternakan juga mempunyai peran dalam membangun psikologis manusia menjadi makhluk hidup yang lebih baik dengan turut serta memelihara alam sekaligus mengembangbiakan hewan-hewan yang hampir punah (Handi, 2013).

Salah satu hewan yang hampir punah adalah burung atau unggas. Burung merupakan hewan bertulang belakang yang sangat bermanfaat bagi manusia, tidak hanya memenuhi kebutuhan nutrisi namun juga memenuhi kebutuhan bagi para penggemar burung. Indonesia tercatat menjadi pemilik dari 1.594 jenis spesies burung dan menjadi negara ke lima terbesar dunia dari 10.000 jenis satwa. Seiring berjalannya waktu akibat kegiatan manusia yang berlebihan seperti melakukan penangkapan hewan, membuka lahan baru dengan cara pembakaran hutan dan pembabatan maka saat ini di dunia hanya berkisar $50 \%$ jenis burung yang masih tetap hidup. Oleh karena itu pelarangan penangkapan burung pun dilakukkan oleh pemerintah terrmasuk pemerintah Indonesia (Ipung, 2014).

Menurut Putera (2014), saat ini peluang usaha penangkaran burung sangat terbuka lebar karena peminat burung semakin banyak namun burung itu sendiri tidak banyak dijumpai di pasaran. Salah satu burung yang memiiki prospek bagus tersebut adalah burung Murai Batu. Pangsa pasar Murai batu sangat tinggi, harga per satu ekor burung dapat mencapai jutaan rupiah.

Penggemar murai batu terdiri dari berbagai lapisan masyarakat, mulai dari orang kota sampai ke pedesaan terpencil dengan tingkat sosial ekonomi yang beragam. Seiring berjalannya waktu burung murai batu yang berasal dari tangkapan liar asli dari hutan kini keberadaan nya mulai langka karena terus menerus diburu serta habitat hidupnya sudah beralih fungsi dan salah satu penyebabnya adalah nilai jual murai batu yang terus naik dari waktu ke waktu. Oleh karena itu agar populasi burung murai batu tidak punah maka perlu dilakukan penangkaran.

Burung Murai Batu merupakan salah satu satwa langka yang sangat menarik karena cerdas dan memiliki kicauan yang sangat baik dengan suara merdu, bermelodi 
dan bervariasi. Selain itu, Murai Batu memiliki gaya yang aktaraktif saat bertarung dan penampilan fisiknya sangat indah. Ukuran tubuh Murai Batu sedang berkisar $27 \mathrm{~cm}$ dengan berat sekitar 32 gram. Paruhnya berwarna hitam tipis dan ukuran kepalanya rata-rata bulat. Jumlah ekor burung Murai Batu ada 12 ekor dengan 4 ekor primer berwarna hitam dan 8 ekor sekunder dengan warna hitam atau putih (tergantung jenisnya). Individu jantan dari burung Murai Batu memiliki warna yang sangat menarik yakni hitam pekat berkilau indigo dengan warna dada pada umumnya berwarna orange sedang individu betina warnanya sedikit pucat dari warna bulu jantan. Bagian pantat dibawah ekor burung Murai baik jantan maupun betina berwarna putih (Handi, 2013).

Bagi para penggemar burung kicauan, Murai Batu adalah jenis burung yang paling banyak dicari terlebih lagi jika burung tersebut adalah burung hasil penangkaran atau peternakan, hal ini dikarenakan burung hasil penangkaran lebih cepat berkicau meskipun berusia muda 9-10 bulan. Berternak burung Murai Batu sangatlah mudah sama seperti berternak jenis unggas lainnya, hanya saja berternak burung Murai Batu memiliki teknik dan cara khusus agar diperoleh burung yang menyuarakan suara seperti yang diinginkan (Wahyu, 2010).

Burung Murai Batu merupakan salah satu tipe burung fighter yang sangat tinggi atau petarung yang handal dan mudah naik darah. Sehingga jika burung tersebut mendengar suara atau melihat burung sejenis maka semangat tarungnya langsung berkobar. Selain fighter burung ini juga memiliki sifat adaptasi yang tinggi sehingga tidak rentan atau sensitif terhadap perubahan lingkungan, selibihnya burung tersebut cepat jinak karena didukung sepenuhnya oleh kemampuan beradaptasi yang tinggi (Turut, 2013).

Burung Murai Batu Medan merupakan jenis burung Murai Batu yang popular, keunikan burung ini menjadi salah satu pembeda dari Murai Batu jenis lain ialah ekornya yang panjang dan berwarna bercak-bercak putih pada bulunya di bagian pangkal ekornya. Serta brand catatan bagi murai batu medan ialah ekor panjang dan melengkung. Menakjubkan kesan yang timbul dari kebagusan murai batu medan menjadi pembeda dari jenis yang lainnya (Bram, 2013).

Kabupaten OKU Timur merupakan salah satu kabupaten yang mempunyai banyak penggemar burung berkicau dan memiliki potensi dalam pengembangan sektor pertanian khususnya penangkaran Murai Batu. Potensi besar ini didasarkan pada semakin tingginya peminat burung berkicau. Pasalnya sering diadakan kontes burung berkicau yang diadakan pemerintah maupun pihak swasta, penggemar yang mengikuti kontes tersebut berasal dari daerah sekitar maupun dari luar daerah seperti daerah Baturaja, Muara Dua, Jambi, Lampung.

Penangkaran Burung Murai Batu ini tidak hanya dilakukkan untuk usaha dalam mendapatkan materi tetapi juga usaha untuk mendapatkan penghargaan dan kepuasan karena Murai Batu merupakan burung kontes yang memiliki daya tarik tinggi.

\section{B. Rumusan Masalah}

Berdasarkan uraian diatas, maka rumusan masalah dalam penelitian ini meliputi :
1. Berapa besar biaya dan pendapatan dari usaha Penangkaran Burung Murai Batu?

2. Apakah usaha Penangkaran Burung Murai Batu layak untuk di kembangkan secara finansial?

\section{Tujuan dan Kegunaan}

Bertolak dari rumusan masalah diatas, maka penelitian ini bertujuan untuk :

1. Mengetahui besarnya biaya dan pendapatan usaha Penangkaran Burung Murai Batu.

2. Mengetahui tingkat kelayakan usaha Penangkaran Burung Murai Batu.

\section{KERANGKA PEMIKIRAN}

\section{A. Tinjauan Pustaka}

\section{Konsepsi Burung Murai Batu}

Murai Batu (Copsychus malabaricus) adalah salah satu burung kicauan yang sangat cerdas. Burung ini mempunyai kemampuan berkicau yang baik serta merdu dan bermelodi dengan sangat variatif. Burung ini termasuk dalam keluarga Turdidae ini ketenarannya sangat tinggi. Ini disebabkan oleh suaranya yang merdu dan kemampuan tarung nya yang aktaktif, dan tidak heran jika harganya juga mahal.

Burung Murai Batu merupakan burung yang mempunyai karakteristik unik yaitu mempunyai lagu merdu, kecerdasan dalam meniru kicauan burung lain serta gaya aktraktif, keunikan ini tidak hanya mampu menjadi daya tarik tetapi membuat burung ini terkenal dengan ciri khas tersendiri. Selain itu, burung Murai Batu merupakan burung yang teritorial, ukuran ekor yang dimiliki dapat mnenunjukkan seberapa luas wilayah yang mereka tempati. Wilayah ini merupakan wilayah sepasang jantan dan betina selama musim kawin (Wahyu, 2010).

Murai Batu dikenal sebagai burung yang mudah naik darah terutama untuk bertarung, hal ini ditunjukkannya apabila mendengar burung Murai Batu lain atau melihat burung sejenis. Selain itu, Murai Batu juga mudah untuk naik birahinya terlebih jika penjemuran berlebihan, penyetelan EF (Extra Fooding) yang berlebihan serta melihat burung betina. Namun disisi lain Murai batu dikenal juga sebagai burung yang mudah beradaptasi dengan lingkungan manusia (Handi, 2013).

Murai jantan dan betina memiliki perbedaan pada warna bulu, dimana murai jantan memiliki warna bulu yang pekat tua, untuk bagian atas hitam maka murai jantan memiliki warna hitam dan berkilau. Sedangkan murai batu betina berwarna pudar untuk bagian atas berwrna hitam dan dada berwarna cokelat pudar. Panjang tubuh murai jantan dapat mencapai $28 \mathrm{~cm}$, sedangkan yang betina panjangnya mencapai $22 \mathrm{~cm}$. Sifat burung ini pemalu akan tetapi kicauannya sangat merdu dan bermelodi dan sangat variasi (Bram, 2013).

Menurut Wahyu (2010), burung Murai Batu yang dikenal di Indonesia terdiri dari:

1. Murai Medan, penyebaran: bukit Lawang, Bohorok, kaki gunung Leuser wilayah Sumatra Utara. Panjang ekor $27-30 \mathrm{~cm}$. 
2. Murai Aceh, penyebaran: di kaki g. Leuser wil. Aceh. Panjang ekor $25-30 \mathrm{~cm}$.

3. Murai Nias, penyebaran: pulau Nias. Panjang ekor 20 $25 \mathrm{~cm}$. Ekor keseluruhan berwarna hitam.

4. Murai Jambi, penyebaran: Bengkulu, Sumatra Selatan, Jambi.

5. Murai Lampung, penyebaran: hidup di Krak atau , Lampung. Ukuran tubuh lebih besar dari Murai Medan. Panjang ekor $15-20 \mathrm{~cm}$.

6. Murai Banjar (Borneo), jenis ini paling populer di Kalimantan, karena sering merajai berbagai lomba di Kalimantan. penyebaran: di Kalimantan Timur dan Kalimantan Selatan. Panjang ekor 10 - $12 \mathrm{~cm}$.

7. Murai Palangka (Borneo), panjang ekor $15-18 \mathrm{~cm}$. penyebaran: Kalimantan Tengah dan Kalimantan Barat.

8. Larwo (Murai Jawa), penyebaran: Jawa Barat, Jawa Tengah dan Jawa Timur. Ukuran tubuh jauh lebih kecil dari murai medan. Panjang ekor $8-10 \mathrm{~cm}$. Jenis ini sudah sangat langka ditemukan. Dari beberapa pemberitaan dikatakan bahwa burung dinyatakan nyaris punah.

Selain dari 8 jenis Murai Batu di atas, ada juga kerabat Murai Batu yang berasal dari negeri tetangga, yaitu :

1. Murai Malaysia, penyebaran: Penang. Ekor tipis dan panjang sekitar 30 - $33 \mathrm{~cm}$ dan postur tubuh lebih besar dari murai medan.

2. Murai Thailand, penyebaran: di perbatasan Thailand dan Malaysia, tubuh lebih besar dari murai medan, panjang ekor 32 - $35 \mathrm{~cm}$ dan warna hitam mengkilat indigo (kebiru-biruan).

3. Murai Filipin, penyebaran: wilayah Luzon dan Catanduanes. Jenis ini lebih tepat disebut Murai Hias, karena memiliki corak warna tubuh yang sangat indah.

\section{Konsepsi Produksi}

Produksi merupakan hasil usahatani yang sangat diharapkan oleh petani. Untuk dapat memperoleh hasil produksi yang maksimal maka diperlukan SDM yang mempuni. Dalam menerapkan teknologi yang tepat guna, tepat waktu dan tepat sasarandapat diwujudkan dengan adanya penerapan manajemen usahatani yang dimilikinya (Suryani, 2005).

Tataniaga hasil pertanian merupakan bagian yang paling lemah dalam mata rantai perokonomian di Indonesia sehingga belum terdapat arti pemasaran yang efisien. Kelemahan ini menyebabkan bagian harga yang diterima petani produsen kurang layak untuk dibandingkan harga pada lembaga tataniaga yang ada. Utuk mengatahui standar keleyakan yang ada maka diperlukan kamampuan dalam memperhitungkan harga dasar sebagai patokan nilai jual terendah yang ditentukan (Istijianto, 2007).

Hasil akhir atau yang lebih dikenal dengan poduksi secara teknis adalah sewktu proses pendayagunaan sumbersumber yang tersedia dengan harapan terwujudnya hasil yang lebih dari segala pengorbanan yang diberikan. Ditinjau dari pengertian ekonomis, produksi adalah proses pendayagunaan segala sumber yang tersedia untuk mewujudkan hasil yang terjamin berkwalitas dan berkwalitas, terkelola dengan baik sehingga merupakan komoditi yang diperdagangkan (Kartasapoetra, 2003).

Produksi adalah hasi akhir dari sebuah proses yang berupa produk (Output). Produk dalam bidang pertanian atau dapat bervariasi antara lain disebabkan karena perbedaan kualitas. Hal tersebut karena kualitas yang baikdihasilkan oleh proses produksi yang baik dan dilaksanakan dengan baik, begitu pula sebaliknya kualitas produksi yang di peroleh kurang baik apabila usaha tersebut dikerjakan dengan usaha yang kurang baik (Asnawi dan Teken, 2005)

Menurut Soekartawi (2001), produksi dalam arti sempit merupakan sebagai suatu hasi yang diperoleh dari proses produksi, yaitu proses memadukan sumberdaya usahatani (input) yang ada sehingga menghasilkan (output). Beasrnya suatu produksi yang dihasilkan ditentukan oleh keputusan tentang mengalokasikan sumberdaya yang terbatas seperti bibit, pupuk, tanah, tenaga kerja, dan lain sebagainya. Beberapa hal yang mendorong petani untuk menaikkan produksi:

1. Perbandingan harga yang menguntungkan

2. Sistem bagi hasil yang wajar

3. Tersedianya barang dan jasa yang ingin dibeli petani untuk keprluan keluarganya.

Faktor-faktor produksi yang sangat menentukan besar kecilnya produksi yang dioeroleh, seperti faktor produksi lahan, modal yang digunakan, tenaga kerja dan sarana produksi. Selain itu, kedudukan lokasi usaha merupakan salah satu faktor lain yang sangat mendukung bagi keberhasilan usahatani, dimana lokasi usaha yang baik adalah lokasi yang ada tidak jauh dari sumber bahan baku, hal tersebut dipandang penting karena dapat mengefisienkan biaya dan margi pemasaran dalam penjualan suatu produkusahatani yang dihasilkan (Asnawi dan Teken, 2005). Untuk menghasilkan produksi produsensuatu usaha yang disebut dengan faktor produksi yang meliputi tenaga kerja, tempat produksi, manajemen, modal, dan skill. Dalam mencapai produksi yang lebih tinggi diperlukan tingkkat penerapan mutu yang berkualitas dengan cara intensifikasi, diversifikasi, dan ekstensifikasi, serta rehabilitasi, maka semakin baik pula produksi yang diperoleh petani (Kartasapoetra, 2009).

Sedangkan menurut Syratiyah (2006), menyatakan bahwa biaya produksi sebagai gambaran untuk mengetahui besarnya biaya dengan tingkat produksi yang dilakukan. Biaya produksi dikelompokan menjadi dua yaitu biaya tetap (fixed cost), dan biaya variabel (variable cost). Biaya tetap yaitu biaya yang tidak habis dalam satu kali proses produksi, misalnya biaya sewa tanah, penyusutan peralatan, sedangkan biaya variabel adalah biaya yang besarnya dipengaruhi oleh besarnya produksi, yang tergolong dalam biaya variabel adala biaya sprodi dan upah tenaga kerja.

\section{Konsepsi Harga}

Suratiyah (2006), menyatakan bahwa harga jual harus dapat menutupi biaya penuh ditambah dengan laba yang wajar. Harga jual sama dengan biaya produksi ditambah Mark-Up. Harga suatu produk merupakan salah satu penentu atas besarnya permintaan pasar yang mempengaruhi posisi persaingan dipasar, sehingga mempengaruhi volume penjualan. Oleh sebab itu harga mempunyai pengaruh yang besar terhadap pendapatan dan laba bersih suatu usaha. Kebijakan harga menjadi penting karena harga sering dijadikan dasar untuk melakukan tindakan, baik oleh pembeli maupun penjual. Hal tersebut dikarenakan transaksi terjadi pada saat terjadi kesepakatan 
harga antara penjual dan pembeli diadakan. Penetapan harga jual dapat ditentukan berdasarkan biaya, tingkat margin, keuntungan dan faktor lain yang mempengaruhinya.

Harga suatu produk merupakan salah satu penentu atas besarnya permintaan pasar. Harga suatu produk mempengaruhi posisi persaingan dipasar, sehingha mempengaruhi volume penjualan oleh karena itu harga mempunyai pengaruh yang besar terhadap pendapatan dan laba bersih perusahaan. Seperti diketahui bahwa harga adalah nilai suatu produk yang diukur dengan unand (in money-tern), dimana berdasarkan nilai tersebut pejual atau produsen bersedia melepaskan barang atau jasa yang dimilikinya kepada hak lain dengan memperoleh keuntungan tertentu (Rahardi, 2003).

Harga merupakan bagian yang sangat penting dalam pemasaran suatu produk karena harga adalah satu dari empat bauran pemasaran $(4 \mathrm{P}=$ product, price, place, promotion $)$. Harga adalah suatu nilai tukar dari produk barang maupun jasa yang dinyatakan dalam satuan moneter. Harga merupakan salah satu penentu keberhasilan agribisnis, harga itu sendiri dapat dipengaruhi oleh beberapa hal seperti waktu,tempat, dan pasar. Dengan harga yang di tukar dengan uang maka seseorang bersedia melepaskan barang atau jasa yang dimilikinya kepada orang lain. Menetapkan harga terlalu tinggi akan menyebabkan penjualan akan menurun, namun jika harga terlalu rendah akan mengurangi keuntungan yang dapat diperoleh organisasi perusahaan. Harag juga merupakan variabel utama yang langsung menentukan seberapa besar jumlah uang masuk. Bertolak dari kenyataan itu maka seyogianya suatu perusahaan agribisnis primer dan agrobisnis yang terkait dengannya mengatur siasat tahunan untuk meminimumkan dampak kejatuhaan harga yang mendekati atau bahkan dibawah ringkat harga pokok (Sjarkowi dan Marwan, 2004).

Kolter (2002) menyatakan untuk menentukan harga pokok dalam suatu produk adalah dengan menghitung keseluruhan biaya produksi dan dibagi dengan hasil produksi, terjadinya kesepakatan harga adalah akibat tawar menawar antara pembeli dan penjual atau antara produsen dan konsumen, harga jual dipengaruhi oleh beberapa faktor yang dikelompokkan menjadi dua yaitu faktor yang dapat dikendalikan oleh petani, meliputi peningkatan mutu, kwalitas, sistem tataniaga, dan faktor diluar jangkaun petani misalnya situasi pasaran diluar negeri, sedangkan penetapan harga merupakan suatu masalah jika perusahaan akan menetapkan harga untuk pertama kalinya. Ini terjadi ketika perusahaan mengembangkan atau memperoleh produk baru, ketika akan memperkenalkan produk barunya kesaluran distribusi baru atau ke daerah baru ketika akan melakukan penawaran atas perjanjian kerja baru. Definisi tersebut menjelaskan bahwa setiap perusahaan harus memutuskan dimana ia akan menempatkan pruduknya berdasarkan mutu dan harga (Kolter, 2002).

Sedangkan untuk menentukan harga pokok dalam suatu produk adalah dengan menghitung keseluruhan biaya produksi dan dibagi dengan hasil produksi, terjadinya kesepakatan harga adalah akibat tawar menawar antara pembeli dan penjual, atau antara produsen dan konsumen, harga jual dipengaruhi beberapa faktor yang dikelompokan menjadi dua yaitu:
1. Faktor-faktor yang dapat dikendalikan oleh petani meliputi peningkatan mutu dan kualitas, sistem tataniaga pemasaran yang dijalankan.

2. Faktor-faktor diluar jangkauan petani, misalnya situasi pasaran diluar negri.

\section{Konsepsi Penerimaan}

Penerimaan adalah jumlah hasil kali antara produksi yang dpieroleh dalam satuan fisik dengan harga jual persatuan fisik. Penerimaan tunai usaha tani didefinisikan sebagai nilai uang yang diterima. Beasrnya penerimaan yang diperoleh petani dari hasil usaha tani yang mereka lakukan berbeda-beda antara petani satu dengan petani yang lainnya. Walaupun luasan garapa dan komoditas yang diusahakan sama. Tujuan akhir dari pengelolaan usaha tani adalah memperoleh pendapatan yang merupakan selisih antara penerimaan dengan biaya yang dikeluarkan diperoleh dalam suatu kegiatan untuk mendapatkan produksi di lapangan pertanian (Soeharjo dan Patong, 2003).

Kegiatan usahatani bertujuan untuk memperoleh produksi dari lahan pertanian, berupa biaya yang dikeluarkan dan penerimaan yang diperoleh. Selisih antara penerimaan dengan biaya usahatani merupakan pendapatan dari kegiatan usahatani. Besar kecilnya pendapatan yang diterima petani dipengaruhi oleh besarnya hasil usaha yang diperoleh, efisiensi tenaga kerja pembagian usahatani, cara pemasaran, cara penggunaan alat dan modal (Soekartawi, 2011).

Penerimaan tunai usahatani sebagai nilai uang yang diterima dari penjualan produk usahatani. Pengeluaran tunai usahatani didefinisikan sebagai jumlah uang yang dibayarkan untuk pembelian barang dan jasa bagi usahatani. Penerimaan tunai usahatani tidak mencakup pinjaman uang untuk keperluan usahatani. Demikian juga pengeluaran tunai uasahatani tidak mencakup bunga pinjaman dan jumlah pinjaman pokok. Penerimaan tunai usahatani tidak mencakup yang berbentuk benda. Jadi, nilai produk yang dikonsumsi tidak dihitung sebagai penerimaan tunai usahatani, dan nilai kerja yang dibayarka sengan benda tidak dihitung sebagai pengeluaran tunai usahatani. Selisih antara penerimaan tunai usahatani dan pengeluaran usaha tani disebut pendapataan tunai usaha tani (farm net cash flow) dan merupakan ukuran kemampuan usahatani untuk menghasilkan uang tunai (Soekartawi, 2005).

Penerimaan merupakan hasil kotor yang diperoleh petani dari hasil penjualan produksi berdasarkan harga jual yang berlaku. Penerimaan yang diperoleh petani dalam melakukan usahataninya memiliki nilai positif apabila lebih besar dari biaya yang telah diinvestasikan selama proses produksi berjalan. Hal tersebut dapat dijadikan sebagai salah satu acauan petani dalam merumuskan dan menentukan kebijakan usaha yang dijalankannya. Petani penangkar burung dapat lebih bersemangat kembali dalam meneruskan usahanya jika penerimaan sementara yang diperolehnya lebih besar dibandingkan dengan biaya produksi yang telah dikeluarkan. Penerimaan dapat diperoleh petani lebih besar dengan adanya hasil produksi yang diperoleh dan diimbangi dengan harga pasar dan pangsa pasar yang signifikan (Soekartawi, 2011). 
Penerimaan merupakan hasil dari produksi usaha dikalikan harga jual persatuan fisik. Dari sini dapat dimengerti bahwa target peningkatan penerimaan harus dinyatakan melalui peran manajerial terhadap tiga variabel terukur yaitu pruduksi, harga dan waktu. Berkanaan dengan variabel produksi sasaran peningkatannya dalam kurun waktu yang segera akan berjalan tentu akan terkait dengan semua variabel pembentuk produksi itu didalam jangka pendek (Sjarkowi dan Marwan, 2004).

Menurut soekartawi dan Ismuwati (2005), penerimaan adalah nilai produk total nilai usaha tani dalam jangka waktu tertentu baik yang dijual maupun yang tidak dijual. Penerimaan usahatani dapat terwujud dalam tiga hal yaitu hasil penjualan tanaman, ternak, ikan atau produk yang akan dijual (hasil produksi), Produk yang dikonsumsi pengusaha dan keluarga selama melakukan kegiatan (dikonsumsi keluarga atau telah dijual), dan kenaikan harga investasi (harga tempat).

Penerimaan usahatani dapar diartikan sebagai besaran keseluruhan hasil produksi yang diperoleh dari hasil produksi usahatani dan diberikan dengan harga yang berlaku saat ini. Selanjutnya didalam penerimaan usaha tani tersebut tidak terlepas dari harga dan produk dimana petani akan menghasilkan suatu produk jika harga memadai, hal ini sesuai dengan pendapatan yang menyatakan bahwa harga salah satu produk dalam pemasaran hasil pertanian (Ibrahim, 2009).

\section{Konsepsi Pendapatan}

Pendapatan usahatani adalah merupakan nilai bersih yang diterima dari hasil usahatani, yang jumlah penerimaan dihitung dengan mengalikan semua total produksi dengan harga yang diterima oleh petani dikurang dengan biaya total. Pendapatan yang tinggi dari hasil usahatani selain ditentukan oleh teknik budidaya dan pemasarannya adalah menetukan standar harga dasar dan pengenalan lembaga pemasaran yang berperan untuk menjualkan anakan burung dari produsen sampai ke konsumen untuk menentukan harga jual yang menguntungkan, tapi juga harus berpedoman pada standar harga dasar.

Dikemukakan Kadarsan (2011) bahwa pendapatan merupakan keuntungan. Peningkatan keuntungan bahwa petani dapat menambah pendapatan petani sehinnga mampu memenuhi seluruh atau sebagian dari kebutuhan keluarga. Keuntungan yang diperoleh petani merupakan selisih antara penerimaan dengan biaya produksi yang memberikan hasil positif yang artinya bahwa apabila penerimaan dikurangi dengan biaya produksi hasilnya harus lebih besar dari nol.

Harga jual ditentukan menurut kelas mutu dimana mutu pertama memiliki tingkat harga lebih tinggi dari tingkat harga kelas mutu yang ada dibawahnya. Dengan demikian dapat diperoleh harag lebih tinggi dibandingkan dengan penentuan harga secara rata-rata. Pendapatan petani dari usahatani merupakan penerimaan dari hasil produksi setelah dikurangi oleh biaya produksi yang dikeluarkannya. Penerimaan petani sendiri merupakan perkalian anatara jumlah produksi dengan harga yang diterima petani. Dengan demikian, penerimaan petani ditentukan oleh produktivitas usahatani serta tinggi rendahnya harga produk. (Saragih, 2011).

Pendapatan merupakan selisih antar penerimaan dengan biaya yang dikeluarkan dan dalam suatu kegiatan untuk mendapatkan produksi di lapangan pertanian karena dalam kegiatan tersebut petani bertindak sebagai pekerja dan penanam modal dalam usahatani, maka pendapatan iti dapat digambarkan sebagai balas jasa dari pekerja faktor produksi yang biayanya dalam waktu tertentu (Soeharjo dan Patong, 2003).

Seperti dikemukakan Teken dan Asnawi (2004) bahwa bagi petani pendapatan merupakan pedoman untuk menilai apakah usaha keluarganya berhasil atau tidak. Biaya total produksi adalah biaya tetap total ditambah biaya variabel total. Semakin banyak output yang dihasilkan, semakin rendah biaya tetap untuk menghasilkan setiap satuan output. Jadi biaya tetap rata-rata cenderung menurun begitu kuantitas output menambah. Sedangkan biaya variabel adalah biaya untuk penggunaan input yang tidak tetap. Semakin banyak memakai input variabel, maka setiap input ekstra menyumbang output semakin sedikit. Besarnya pendapatan tunai atau proporsi penerimaan tunai termasuk antara yang dapat digunakan sebagai perbandingan keberhasilan antara petani. Pendapatan yang lebih tinggi merupakan alasan utama bagi petani untuk menambah cabang sebuah usaha baru.

Menurut Sjarkowi (2011) bahwa pendapatan merupakan selisih antara penerimaan dengan biaya yang dikeluarkan dan dalam suatu kegiatan produksi untuk mendapatkan produksi di lapangan pertanian, karena dalam kegiatan di atas petani bertindak sebagai pngelola.

Besarnya pendapatan tunai atau proporsi penerimaan tunai termasuk antara yang dapat digunakan sebagai perbandingan keberhasilan antara petani. Pendapatan yang lebih tinggi merupakan alasan utama bagi petani untuk menambah cabang sebuah usaha baru. Oleh karena itu petani perlu membuat perbandingan apakah perlu mengganti usaha yang kurang menguntungkan atau menambah usaha yang telah ada (Soeharjo dan Patong, 2003).

Pendapatan dalam ilmu ekonomi dapat didefinisikan sebagai hasil berupa uang atau materi lainnya yang dicapai dari penggunaan kekayaan atau jasa manusia bebas. Sedangkan pendapatan rumah tangga adalah total pndapatan dari setiap anggota dalam bentuk uang yang diperoleh baik sebagai gaji atau upah rumah tangga atau sumber lain. Besarnya pendapatan usaha merupakan gambaran dari keadaan input, output, dan teknologi lain yang ditetapkan oleh produsen dalam kegiatan usahanya. Pendapatan terdiri dari pendapatan kotor dan pendapatan bersih. Pendapatan kotor adalah seluruh pendapatan yang diperoleh dari semua cabang dan sumber didalam usaha dalam satu tahun yang diperhitungkan dari hasil penjualan, pertukaran atau penafsiran kembali. Sedangkan pendapatan bersih adalah selisih dari total pendapatan dan total biaya setelah dikurangi dengan pajak pendapatan (Nuryanti, 2012).

\section{Konsepsi Kelayakan Usaha}

Studi kelayakan akhir-akhir ini telah banyak dikenal oleh masyarakat, terutama masyarakat yang bergerak dalam bidang dunia usaha bermacam-maacam peluang dan kesempatan yang ada dalam kegiatan dunia usaha, menuntut perlu adanya penilain sejauh mana kegiatan atau kesempatan tersebut dapat memberikan manfaat (benefit) bila diusahakan. 
Kegiatan untuk menilai sejauh mana manfaat yang di peroleh dalam melaksanakan suatu kegiatan usaha, disebut dengan studi kelayakan bisnis. Studi kelayaka bisnis yang disusun merupakan pedoman kerja, baik dalam penanaman investasi, pengeluaran biaya, cara produksi, cara melaksanakan pemasaran dari hasil produksi, dan cara dalam menentukan jumlah tenega kerja serta jumlah pemimpin yang diperlukan. Layaknya gagasan usaha dalam sebuah studi kelayakan bisnis, apabila kegiatan usaha yang dijalankan berdasarkan kegiatan usaha yang telah diatur oleh studi kelayakan dalam keadaan ini tidak menjamin kegiatan usaha apabila tidak dikerjakan selaras dengan kegiatan yang telah diatur dalam sebuah studi kelayakan (Soekartawi, 2005)

Peranan studi kelayakan dan analisis proyek dalam kegiatan pembangunan cukup besar dalam mengadakan penilain terhadap kegiatan uasha yang akan dilaksanakan. Demikian pula terhadap pengusaha ekonomi lemah, pada umumnya masalah yang dihadapi para pengusaha, selain keterbatasan modal, serta keterbatasan sumber daya dalam melihat usaha yang di kembangkan. Hal ini merupakan masalah baru yang memerlukan pemechan secara terpadu untuk mengembangkan usaha (Mubyarto, 2004).

Faktor-faktor yang perlu dinilai dalam menyusun studi kelayakan bisnis adalah menyangkut dengan beberapa aspek antara lain aspek marketing, aspek teknis produksi, aspek manajemen, aspek lingkungan dan aspek keuangan. Dengan demikian apabila gagasan usaha yang telah dinyatakan layak dsri segi ekonomi, dalam pelaksanaan jarang mengalami kegagalan kecuali disebabkan oleh faktor-faktor dari bencana alam.

Dengan demikian studi kelayakan yang juga sering dengan feasibility studi merupakan bahan pertimbangan dalam mengambil suatu keputusan, apakah menerima atau menolak dari suatu gagasan usaha yang teleh direncanakan. Pengertian layak dalam penelitian ini adalah kemungkinan dari gagasan usaha yang akan dilaksanakan memberikan manfaat (benefit), baik dalam arti financial benefit, hal ini tergantung dari segi penilaian yang dilakukukan (Soekartawi, 2005).

Menurut Umar (2000), studi kelayakan usaha adalah suatu penelitian tentang layak atau tidaknya suatu usaha yang biasanya merupakan proyek investasi itu biasanya dilaksanakan. Arti layak atau tidak layak disini adalah perkiraan bahwa proyek akan atau tidak dapat dilaksanakan menghasilkan keuntungan yang layak bila dioperasionalkan. Hasil studi kelayakan usaha merupakan hasi tindak lanjut dari keputusan manajemen pada fungsi perencanaan berdasarkan informasi yang tersedia, baik dari informasi internal maupun eksternal.

Menurut Syarkowi (2010), studi kelayakan usaha dibedakan menjadi tiga yaitu studi kelayaka teknis, finansial, dan ekologis. Studi kelayakan teknis merupakan langkah persiapan formal yang paling awal untuk memulai suatu rencana yang mengisyaratkan peran-peran dari adanya korbanan saprodi atau input berupa sumber daya (alami, insan, dan buatan), adanya proses (produksi-pembuatan-standarisasipengepakan) yang sifatnya mendayagunakan sumberdaya itu dan adanya hasil atau output yang harus bernilai tambah dan mendatangkan laba yang mendapatkan tambahan pendapatan suatu usaha.

Studi kelayakan finansial mempertimbangkan beberapa kenyataan dinamis yang terkait dengan time value of maoney (nilai uang menurut waktu), seperti NPV, IRR, Net B/C. Sedangkan untuk kelayakan ekologi merupakan analisis khusus dampak proyek terhadap lingkungan hidup yang meliputi lingkungan alami, lingkungan sisoal, dan binaan atau sering disebut dengan AMDAL, atau analisis mengenai dampak lingkungan (Syarkowi, 2010)

\section{Konsepsi Agribisnis}

Keberhasilan suatu kegiatan produksi dari satuan agribisnis adalah yang manapun tentunya terletak pada kadar hasil produksinya. Sungguhpun kegiatan usaha agribisnis banyak tergantung pada kemurahan alam, namaun kadar keberhasilan itu masih dapat diarahkan kepada tingkatan capaian yang dikehendaki dengan siasat pendekatan dan management produksi. (Sarjkowi dan Marwan, 2004).

Agribisnis merupakan setiap usaha komersilyang berkaitan dengan produksi pertanian, yaitu berupa sarana kegiatan produksi (input) pertanian maupun pengusaha produksi pertanian itu sendiri dan pengelolaan hasil (output) pertanian. Adapun masalah yang perlu dijadikan focus kajian management agribisnis, berarti melacak kejanggalan terhadap apa yang normal. Pada mulaya agribisnis mempunyai pengertian perusahaan yang hanya bergerak pada kegiatan jual dan beli barang-barang seperti traktor, pupuk dan pestisida atau tergabung dalam berbagai saprodi (sarana produksi) pertanian saja. Perkembangan kearah batasan pengertian yang luas itu telah didorong oleh adanya kemajuan yang dicapai dibidang produksi pertanian, disamping perusahaan-perusahaan penyedia saprodi pertanian setiap satuan perusahaan yang berada di kedua sub sektor usaha (input dan output) pertanian itu kemudian digolongkan sebagai perusahaan agribisnis. Adapun teknik mengidentifikasi (mengenal dan melacak) masalah pembangunan sebagai suatu kegiatan produktif suatu satuan agribisnis biasanya dengan tiga ciri proses yaitu:

1. Fungsionsal anatomois yaitu untuk hubungan internal yang secara kompatemental menentukan efisiensi dan efektifitas kelola keuangan, ketenagakerjaan, produksi dan pemasaran.

2. Fungsional morfologis yaitu bentuk kesiapan kerjasama interaktif dengan para calon mitra usaha baik berupa penyediaan bahan baku, pembeli, penegak hukum dan bahan asing

3. Fungsional ekologis yaitu antisipasi terhadap kinerja alam dan sosial ekonomi budaya dan yang terkait secara langsung dengan produksi dan nilai cipta, nilai tambah produk pertanian dan produk turunannya.

Setiap maksud mendirikan agribisnis seharusnya memperhitungkan kesesuaian biogiofisik alam, juga ketersediaan modal sarana dan prasarana menurut Sjarkowi dan Sufri (2004). Setiap satuan agribisnis yang sedang di rencanakan sesungguhnya merupakan mekanisme kegiatan produksi yang di potong oleh tiga unsur yaitu saprodi (input), proses produksi dan output atau hasil.

Fungsi produksi merupakan informasi penting yang bisa menunjukkan kearah kiprah suatu agribisnis . Dalam mengatur strategi pemasaran dapat digunakan kaedah P-4 sebagai stategi kelola serba siasat. Kaedah itu yaitu berupa produk, penerimaan penempatan, dan promosi. Keempat 
faktor tersebut harus dilaksanakan dan diperhatikan secara baik dan benar karene itulah nantinya yang dapat menentukan keberhasilan seseorang pedagang dalam memasarkan barang atau produk yang diusahakannya (Sjarkowi, 2010).

Secara konsepsional sistem agribisnis adalah semua aktivitas mulai dari pengadaan dan penyaluran sarana produksi sampai kepada pemasaran produk yang dihasilkan oleh usaha tani dan agroindustri yang terkait satu sama lain. Sistem agribisnis merupakan sustu konsep yang menempatkan kegiatan pertanian sebagai suatu kegiatan yang utuh dan komperhensif sekaligus sebagai suatu konsep yang dapat menelaah dan menjawab berbagai masalah dan tantangan (Firdaus, 2008).

Sedangkan menurut Saragih (2004), agribisnis adalah kegiatan yang berhubungan dengan penanganan komoditi pertanian, sedangkan dalam arti luas agribisnis meliputi salah satu atau keseluruhan dari mata rantai produksi yaitu pengolahan masukan dan keluara produksi, pemasaran masukan dan keluaran pertanian serta kelembagaan penunjang kegiatan. Berhubungan yang dimaksud adalah kegiatan usaha yang menunjang kegiatan pertanaian dan kegiatan usaha yang ditunjang oleh kegiatan pertanaian.

Keberhasilan suatu kegiatan agribisnis sangat tergantung pada strategi pengolahan dan ketepatannya tergantung pada tiga tempat yaitu tepat investasi, tepat administrasi, tepat kepemimpinan. Kegiatan suatu agribisnis tidak bisa berjalan tanpa adanya uang yang diputarkan, karena dengan adanya kelancaran arus uang, maka sumberdaya manusia sebagai tenagakerja proses produksi dapat berjalan dengan seterusnya pemasaranpun dapat direalisasikan. Kegiatan agribisnis dapat berjalan dengan baik apabila administrasi dibidang keuangan, kepegawaian, produksi, dan pemasaran berjalan sesuai dengan manajemen (Sjarkowi, 2010).

\section{B. Model Pendekatan}

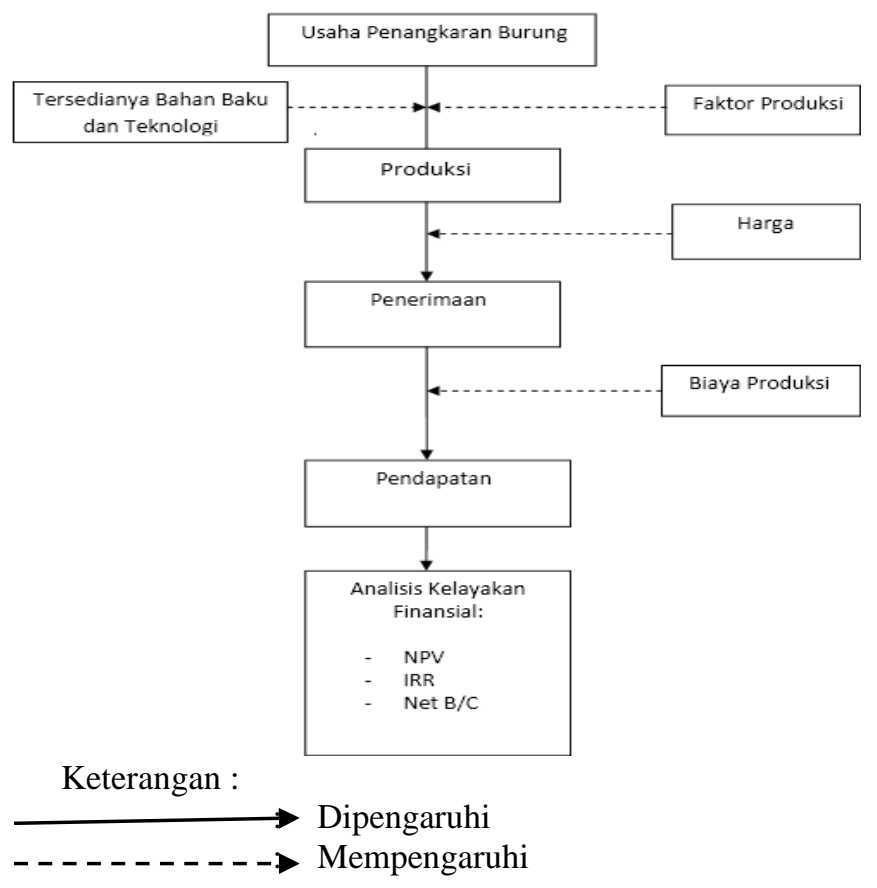

Gambar 1. Model Pendekatan Diagramatis Analisis Usaha penangkaran Burung Murai Batu

\section{METODOLOGI PENELITIAN}

Penelitian ini telah dilaksanakan di Desa Sidogede Kecamatan Belitang Kabupaten OKU Timur dan di Desa Bangun Harjo Kecamatan Buay Madang Timur Kabupaten OKU Timur. Penentuan lokasi penelitian secara sengaja (purposive), dengan pertimbangan bahwa di daerah tersebut ada usaha penangkaran burung murai batu yang keberadaannya sudah mulai susah dijumpai di alam. Penelitian ini telah dilaksanakan pada bulan Maret 2017.

\section{A. Metode Penarikan Contoh}

Metode penelitian yang digunakan adalah metode survey, metode survey merupakan metode penelitian dimana peneliti mengunjungi dan mengambil data untuk memperoleh fakta-fakta dan mencari keterangan-keterangan secara faktual. Fakta dan keterangan yang dicari dalam penelitian ini yaitu mengenai bagaimana proses dalam penangkaran burung murai batu guna memperoleh informasi yang dibutuhkan.

Metode penarikan contoh dalam penelitian ini adalah dengan menggunakan metode sensus terhadap dua sampel dari dua populasi usaha penangkaran burung murai batu di Desa Sidogede Kecamatan Belitang Kabupaten OKU Timur dan di Desa Bangun Harjo Kecamatan Buay Madang Timur Kabupaten OKU Timur.

\section{B. Metode Pengumpulan Data}

Data yang dikumpulkan dalam penelitian ini terdiri dari data primer dan data sekunder. Data primer adalah data yang diperoleh dari hasil observasi dan wawancara langsung dengan orang yang terlibat didalamnya. Observasi yakni melakukkan pengamatan dan pencatatan secara cermat dan sistematis untuk mendapatkan hasil sesuai sasaran. Wawancara langsung dilakukkan dengan narasumber atau petani yang melakukan penangkaran Burung Murai Batu dengan cara melakukkan tanya jawab langsung mengenai kegiatan penangkaran Burung Murai Batu. Data sekunder adalah data yang berasal dari buku, internet, instansi pemerintah maupun tinjauan pustaka.

\section{Metode Pengolahan Data}

Data yang diperoleh dari lapangan akan diolah secara tabulasi dan matematis, yang meliputi biaya produksi, penerimaan, pendapatan, menghitung R/C Ratio, dan menganalisis kelayakan finansial.

1. Untuk menghitung Pendapatan

a. Untuk menghitung biaya produksi menggunakan rumus (Suratiah, 2006)

$\mathrm{TC}=\mathrm{FC}+\mathrm{VC}$.

(1)

Keterangan:

$\mathrm{TC}=$ Total Cost (Biaya Total)

$\mathrm{FC}=$ Fixed Cost (Biaya Tetap)

$\mathrm{VC}=$ Variabel Cost (Biaya Variabel)

b. Untuk menghitung penerimaan menggunakan rumus (Suratiah,2006).

$\mathrm{TR}=\mathrm{P} \times \mathrm{Q}$.

(2)

Keterangan: 


$$
\begin{aligned}
\text { TR } & =\text { Total Revenue (Total Penerimaan) } \\
\text { P } & =\text { Price (Harga Produk Persatuan) } \\
\text { Q } & =\text { Quantity (Jumlah Produksi) }
\end{aligned}
$$

c. Untuk menghitung pendapatan menggunakan rumus (Suratiah, 2006).

$\mathrm{I}=\mathrm{TR}-\mathrm{TC}$.

Keterangan:

$$
\begin{aligned}
& \mathrm{I}=\text { Pendapatan } \\
& \mathrm{TR}=\text { Total Revenue (Penerimaan Total) } \\
& \mathrm{TC}=\text { Total Cost (Total Biaya) }
\end{aligned}
$$

2. Untuk menganalisis kelayakan finansial sebagai berikut:

a. Net Present Value ( NPV) nilai kini bersih (Ibrahim, 2009)

$$
\mathrm{NPV}=\sum_{i=1}^{n} \mathrm{~N} \overline{\mathrm{B}} i(1+i)^{-n}
$$

Keterangan:

$$
\begin{aligned}
\mathrm{NPV} & =\text { Net Present Value } \\
\mathrm{NB} & =\text { Net Benefit }=\text { Benefit }- \text { Cost } \\
\mathrm{i} & =\text { Discount factor (tingkat suku bunga) } \\
\mathrm{n} & =\text { tahun ( waktu) }
\end{aligned}
$$

b. Internal Rate of Return (IRR) laju keberhasilan usaha (Ibrahim, 2006)

$$
\mathrm{IRR}=\mathrm{i} 1+\frac{\mathrm{NPV} 1}{(\text { NPV1-NPV2) }} X(i 2-i 1) \ldots
$$

Keterangan:

NPV1 = NPV pada tingkat discount rate tertinggi (positif)

NPV2 = NPV pada tingkat discount rate terendah (negatif)

$\mathrm{i} 1$ = Tingkat discount rate yang menghasilkan NPV1

i2 = Tingkat discount rate yang menghasilkan NPV2

c. Net B/C Ratio (Ibrahim, 2006)

$$
\text { Net } B / C=\frac{\sum_{i=1}^{n} N B i(+)}{\sum_{i=1}^{n} N B i(-)}
$$

Keterangan:

Net $\mathrm{B} / \mathrm{C}>0$ berarti usaha tersebut layak dikembangkan Net $\mathrm{B} / \mathrm{C}=$ oberarti usaha tidak untung tidak rugi (impas) Net $\mathrm{B} / \mathrm{C}<0$ berarti usaha tidak menguntungkan (rugi)

\section{HASIL DAN PEMBAHASAN}

\section{A. Analisis Usaha Penangkaran Burung Murai Batu}

Analisis merupakan aktivitas yang memuat sejumlah kegiatan seperti mengurai, membedakan, memilih sesuatu untuk digolongkan dan dikelompokan kembali menurut kriteria tertentu kemudian dicari kaitannya dan ditaksir maknanya. Dalam menganalisis sebuah usaha yang dikembangkan atau diusahakan, harus diteliti secara hati-hati karena kesalahan sekecil apapun akan berdampak dalam analisis yang kita lakukan, mulai dari investasi awal, seperti biaya produksi yang dikeluarkan hingga keuntungan yang diperoleh. Adapun analisis usaha peternakan burung murai batu yang ada di Desa Sidogede Kecamatan Belitang dan di Desa Bangun Harjo Kecamatan Buay Madang Timur adalah sebagai berikut :

\section{Biaya Produksi Pada Penangkaran Burung Murai Batu}

Setiap pengolahan usaha berupaya untuk mendapatkan hasil yang optimal sampai kepada maksimal. Untuk memenuhi hal tersebut maka diperlukan pembiayaan dalam kegiatan proses produksinya. Pembiayaan yang dikeluarkan untuk kegiatan proses produksi disebut juga dengan biaya produksi. Biaya produksi adalah biaya yang dikeluarkan oleh peternak selama proses produksi. Biaya ini terdiri dari biaya tetap (Fixed Cost) dan biaya tak tetap (Variable Cost).

Tabel 1. Biaya Tetap Satu Kali Produksi Penangkaran Burung Murai Batu.

No Uraian $\begin{gathered}\text { Jumlah } \\ \text { (Rp/Proses) }\end{gathered}$

1. Biaya Tetap

\begin{tabular}{|c|c|c|}
\hline No & Uraian & $\begin{array}{c}\text { Jumlah } \\
\text { (Rp/Proses) }\end{array}$ \\
\hline \multirow[t]{8}{*}{1.} & Biaya Variabel & \\
\hline & a. Jangkrik & 25.000 \\
\hline & b. Kroto & 100.000 \\
\hline & c. Voer & 16.000 \\
\hline & d. Vitamin & 20.000 \\
\hline & e. Listrik & 120.000 \\
\hline & f. Tenaga Kerja & 320.000 \\
\hline & Jumlah Biaya Variabel & 601.000 \\
\hline
\end{tabular}
a. Sewa Tempat
110.000
b. Penyusutan Alat
40.225
c. Indukan Jantan
350.000
d. Indukan Betina
200.00

\begin{tabular}{cc}
\hline Jumlah biaya Tetap & 700.225 \\
\hline
\end{tabular}

Sumber: Olahan Data Primer, tahun 2017

Tabel 2. Biaya Variabel Satu Kali Produksi Penangkaran Burung Murai Batu.

Sumber: Olahan Data Primer, tahun 2017

Tabel 3. Total Biaya (TC)

\begin{tabular}{ccc} 
No & Uraian & Jumlah (Rp/Proses) \\
\hline 1. & Biaya Tetap & 700.254 .86 \\
2. & Biaya Variabel & 601.000 \\
\hline & & $1.301 .256,86$ \\
\hline
\end{tabular}

Sumber: Olahan Data Primer, tahun 2017

2. Produksi, Penerimaan dan Pendapatan Usaha Penangkaran Burung Murai Batu

Produksi dalam kegiatan usaha penangkaran burung murai batu adalah jumlah produk yang dihasilkan dari usaha peternakan dalam bentuk anakan burung dan harga yang telah ditetapkan penangkar. Pada penangkaran burung murai batu rata-rata jumlah anakan dalam satu kali proses produksi 2-3/ekor dengan harga yang berbeda antara anakan jantan dan betina, baik responden I atau II 
untuk anakan jantan dengan harga rata-rata $\mathrm{Rp}$ 2.000.000/ekor sedangkan anakan betina $\mathrm{Rp}$ 1.000.000/ekor.

Penerimaan adalah jumlah dari hasil produksi yang diperoleh penangkar dikalikan dengan harga jual dalam satu kali proses produksi. Penerimaan penangkar dari usaha penangkaran burung murai batu sebesar Rp 17.000.000/proses.

Tabel 4. Jumlah Produksi dan Penerimaan Usaha Penangkaranan Burung Murai Batu

\begin{tabular}{cccc} 
Produksi & $\begin{array}{c}\text { Jumlah } \\
\text { (Ekor) }\end{array}$ & $\begin{array}{c}\text { Harga } \\
(\mathbf{R p})\end{array}$ & Penerimaan \\
\hline Anakan Jantan & 4 & 2.000 .000 & 8.000 .000 \\
Anakan Betina & 5 & 1.000 .000 & 5.000 .000 \\
\hline
\end{tabular}

Sumber: Olahan Data Primer, tahun 2017

\section{Pendapatan Pada Usaha Penangkaran Burung Murai Batu}

Pendapatan merupakan nilai bersih yang diterima oleh responden dalam kegiatan usaha penangkaran, pendapatan adalah selisih antara penerimaan dengan seluruh biaya produksi. Dalam satu kali proses produksi, pendapatan penangkar dari usaha penangkaran burung murai batu adalah :

Tabel 5. Jumlah Pendapatan Usaha Penangkaran Burung Murai Batu di Kabupaten OKU Timur

\begin{tabular}{lcc} 
No & Uraian & Jumlah (Rp/Proses) \\
\hline 1. & Penerimaan & 13.000 .000 \\
2. & Biaya Produksi & $1.301 .254,86$
\end{tabular}

\begin{tabular}{cc}
\hline Jumlah Pendapatan & $11.689 .745,14$ \\
Sumber: Olahan Data Primer, tahun 2017
\end{tabular}

\section{Analisis Kelayakan Finansial}

a. Analisi NPV (Net Present Value)

Untuk menghitung NPV maka perlu diketahui terlebih dahulu besarnya modal awal atau investasi awal yang dikeluarkan untuk usaha penangkaran Burung Murai Batu di Kabupaten OKU Timur. Setelah diketahui besarnya modal awal dan biaya oprasional maka selanjutnya adalah menghitung NPV (Net Present Value) dengan tingkat suku bunga $18 \%$

Table 6. Analisis Finansial

1 ketperet|latev|

\begin{tabular}{|c|c|c|c|c|c|c|c|c|c|}
\hline Then & Inetzilial & Orasinal & Bapiotal & $\begin{array}{c}\text { Beret: } \\
\text { Penerinan| }\end{array}$ & 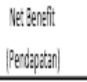 & $\begin{array}{l}\text { of } \\
1.8 \%\end{array}$ & $\begin{array}{l}\|:\| \\
18 \%\end{array}$ & $\begin{array}{l}\text { DF } \\
728\end{array}$ & $\begin{array}{l}1 \% \\
12 \%\end{array}$ \\
\hline & $0 \quad 354211500$ & & 35992150 & & (3542015:50) & 1 & $\mid 35921150.0$ & 1 & {$[59921.50 \mid$} \\
\hline & 1 & 156015156333 & 156615158333 & 13600000 & 140.88494.,7] & 0,07 & 11899122095 & 05881 & 69160772,29 \\
\hline & ? & 31220111667 & 3122011.1607 & 312000000 & $20.76268083,3$ & 0778 & 201645856 & 0,338 & $9.965 .520,5.5$ \\
\hline & 3 & 46855.17300 & 4685.517 .90 & 48000000 & (21.154862,0 & 0,099 & 766327.88 .87 & 0.997 & $82760.52,49$ \\
\hline & 4 & 6260133332 & 6264223333 & 624000000 & 50.153276 .69 .7 & 0,56 & 286659646 & 0,114 & 6460630,16 \\
\hline & j & 70.07529167 & 78075261.67 & 70.000000 & 70.461703 & 0.47 & 3681773991. & 0,060 & 46628161,19 \\
\hline \multicolumn{5}{|c|}{ lumbet } & \multicolumn{2}{|c|}{ Nith } & $8137.7990 \mathrm{FF}$ & & 1228.371. \\
\hline
\end{tabular}

Sumber: Olahan Data Primer, tahun 2017

Total nilai NPV + adalah $-359.921 .500+118.970 .289,5+$ $201.644 .558,6+256.327 .828,7+289.635 .964,6+$ $306.817 .759,1=813.474 .900$ b. Analisis IRR (Internal Rate of Return) Laju Kebersihan Usaha

$$
\begin{aligned}
\operatorname{IRR} & =11+\frac{\mathrm{NPV1}}{(\mathrm{NPV1}-\mathrm{NPV2})} X(i 2-i 1) \\
\mathbb{R R} & =18 \%+\frac{813,474,900}{(813,474,900-(-2,291,371)} X(72 \%-18 \%) \\
& =71,8 \%
\end{aligned}
$$

Pada nilai IRR $71,8 \%$ artinya usaha yang dilakukan memberikan keuntungan sebesar 71,8\% > suku bunga bank yang berlaku kini $18 \%$ maka usaha layak untuk dikembangkan

c. Nilai Net B/C Ratio usaha penangkaran burung murai batu

Untuk mengetahui Nilai Net B/C Ratio adalah sebagai berikut:

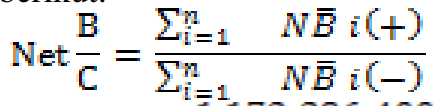

$$
\begin{aligned}
& \text { Net } B / C=\frac{1.173 .396 .400}{359.921 .500} \\
& =3.26
\end{aligned}
$$

Dengan kriteria

Net B/C > 0 berarti usaha tersebut layak dikembangkan Net $\mathrm{B} / \mathrm{C}=0$ berarti usaha tidak untung tidak rugi (impas) Net $\mathrm{B} / \mathrm{C}<0$ berarti usaha tidak menguntungkan (rugi)

Kesimpulan Nilai Net B/C Ratio Pada nilai NPV yang telah di discount factor pada usaha penagkaran burung murai batu didapat sebesar 3.26 Nilai ini $>0$ yang artinya usaha penangkaran burung murai batu layak untuk dikembangkan.

\section{KESIMPULAN DAN SARAN}

\section{A. Kesimpulan}

Berdasarkan hasil penelitian yang telah dilakukan maka dapat ditarik kesimpulan, sebagai berikut :

1. Besarnya penerimaan usaha penangkaran burung murai batu adalah sebesar Rp. 13.000.000, dengan total biaya sebesar Rp. 1.301.254,86 sehingga dapat diperoleh pendapatan sebesar Rp. 11.689.745,14

2. Analisis NPV (Net Present Value) pada usaha penangkaran burung murai batu adalah sebesar Rp 813.474.900. Dengan nilai IRR (Internal rate of Return) adalah $71,8 \%$ artinya lebih besar dari suku bunga bank $18 \%$, sehingga usaha penangkaran burung murai batu layak untuk dikembangkan. Nilai Net B/C adalah sebesar 3,26 yaitu lebih besar dari nol maka usaha layak untuk dikembangkan.

\section{B. Saran}

Saran yang dapat peneliti berikan berdasarkan hasil penelitian adalah sebagai berikut :

1. Hendaknya pemerintah daerah turut mendukung dan memperhatikan usaha penangkaran burung murai batu yang keberadaannya hampir susah di temui di alam dan juga lebih sering diadakan kontes burung berkicau. 
2. Bagi pelaku usaha agar lebih memperhatian perawatan burung agar kondisinya lebih baik lagi dan dapat menghasilkan burung kicau yang lebih berkualitas.

\section{DAFTAR PUSTAKA}

Ariadi B. Y. Dan Relawati R. 2011. Sistem agribisnis Terintegrasi Hulu-Hilir. Muara Indah. Bandung

Bram, M. 2013. Buku pintar burung-burung kicauan. Flashbook. Jogjakarta.

Handi. 2013. Rahasia Memasterkan Murai Batu. Pustaka Baru Press. Yogyakarta.

Ipung. $2014 . \quad$ Murai Batu. http://ipunkkicaumania.blogspot.com/p/muraibatu.html. Diakses pada tanggal 06 Oktober 2015.

Kadarsan, T 2011. Dasar-dasar Manajemen. LP3S. Jakarta.

Kotler, P 2002. Manajemen Pemasaran. Prenhalindo. Jakarta.

Mubyarto, 2002. Pengantar Ilmu Pertanian. Lembaga penelitian. Jakarta.

Putera. 2014. Merawat Burung. http: atau atau merawatburung.blogspot.com atau 2014 atau 02 atau daftarharga-burung-murai-batu-bulan-pebruari-2014.html. Diakses pada tanggal 06 Oktober 2015.

Rahardi, F. 2003. Mengubah Rintangan Menjadi Peluang Berinvestasi. PT. Agromedia. Jakarta.

Saragih, B. 2001. Membangun Pertanian Prespektif Agribisnis. Pertanian Mandiri. Jakarta.

Sjarkowi, F dan Marwan, S 2004. Manajemen Agribisnis. CV. Baldad Grafitri Pres. Palembang.

Soekartawi. 2001. Agribisnis Teori dan Aplikasinya. PT Gravindo Persada. Jakarta.

Soekartawi. 2002. Teori Ekonomi Produksi. Rajawali. Jakarta.

Soekartawi. 2005. Prinsip Dasar Ekonomi Pertanian. Raja Grafindo Persada. Jakarta

Suratiyah,K 2006. Ilmu Usaha Tani. Swadaya. Jakarta.

Sudarso. 2012. Wisata Kicau. http: atau atau wisatakicau.blogspot.com atau p atau blog-page 7.html. Diakses pada tanggal 06 Oktober 2014.

Teken dan Asnawi. 2005. Teori Ekonomi Makro. Erlangga. Jakarta.

Turut, R. 2013. Murai Batu. Swadaya. Jakarta.

Vernahy. 2013. Tips Belajar Untuk Beternak Murai Batu. http: atau atau infomurai.blogspot.com atau 2013 atau 03 atau tips-belajar-untuk-beternak-murai-batu.html. Diakses pada tanggal 06 Oktober 2015.

Wahyu. 2010. Beternak Murai Batu. http: atau atau refreshindonesia.com atau muraibatu atau ?p=110. Diakses pada tanggal 06 Oktober 2015. 